\title{
Application of Information and Communication Technology in English Coursebooks ${ }^{1}$
}

\begin{abstract}
The aim of this paper is to discuss the integration of Information and Communication Technology (ICT) into current English Language Teaching coursebooks in the seventh grade of the new Polish primary school (in line with the new core curriculum). The theoretical underpinnings of ICT application into language learning along with enumerating the requirements regarding ICT tools in the new core curriculum are followed by a description of the research carried out in order to establish which ICT tools are integrated or ignored in the current ELT textbooks. Six of the eight student's books available on the market were selected for this purpose. The quantitative analysis covered the ICT content in these textbooks. The essence of the research was to establish which coursebook contains the biggest number of references to ICT, what types of references they are (explicit or implicit ones), and, finally, to discover to what extent information society is portrayed in them. The results prompted demands for supplementing the criteria for the evaluation of textbooks with the intensity of references to ICT.
\end{abstract}

Keywords: ICT, ELT, coursebook, textbook.

\section{Introduction}

The year 2017 brought about a fundamental shift in the system of education in Poland. The Ministry of National Education introduced a thorough reform: middle schools (Polish gimnazjum) were shut down and both eight-grade primary school (Polish szkoła podstawowa - SP) and a 4-year high school were restored. In addition to many other challenges that this reform had to face (e.g. either too small or too big school facilities, parents' and teachers' habits and routines), it caused the necessity to introduce new core curricula to the seventh and eighth grades of the SP, which had not existed in the course of the 20 previous years. As a result, the new Core Curriculum of General Education (CC) was created, introducing new standards to teaching and learning of foreign languages. Hence the teachers of English as a Foreign Language (EFL) were faced with quite

1 This article has received financial support from the Polish Ministry of Science and Higher Education under subsidy granted to the Faculty of Philology, University of Białystok for R\&D and related tasks aimed at development of young scientists and $\mathrm{PhD}$ students. 
a limited variety of newly written coursebooks, which had to be thoroughly evaluated and eventually selected for use in the upcoming school year.

The ability to evaluate a coursebook is an important competence in the EFL teacher's everyday work (Kusiak-Pisowacka 2015: 71), but the analysis of the entire core curriculum and confronting it with all English textbooks for the newly created seventh grades seemed to be a venture beyond the volume of this publication. Therefore, the primary objective of this article is to verify which information and communication technology (ICT) tools listed in the CC are most often used in the aforementioned textbooks. In addition, it is also necessary to analyze how these tools are referred to in these textbooks. Because, as Ostrowska and Sterna (2015: 33) rightly point out, the mere introduction of computers into classes is not enough to improve teaching, and the use of ICT tools during lessons is not the teachers' goal. It is about developing such a concept of applying new technologies which will enrich students' competences, and so that teachers should be guided by the overarching learning objectives, written in the core curriculum, and the educational requirements contained therein.

The rationale for conducting the research described in this article was first and foremost of all the publication of completely new EFL coursebooks and therefore completely new material, not previously scrutinized by any investigation. What is more, a study of such a character is a rare case, exemplified by Hismanoğlu (2011) and Rybarczyk (2006). The former critically analysed the integration of information and communication technology into English Language Teaching (ELT) coursebooks available world-wide, published between 2003 and 2007, and hence quite outdated. The latter analysed only the content of websites dedicated to coursebooks used in teaching German in Polish middle schools, thus making it less interesting from the point of view of an EFL teacher.

Additionally, the report on the implementation of the foregoing core curriculum confirmed the dominance of textbooks as the basic teaching materials used in Poland in foreign language lessons, both in the primary and middle schools. The final reason lied in the conclusions drawn from scrutinizing a process modern societies are currently undergoing: a trend to create a fully informative society, based on knowledge and the use of the latest digital technologies. Therefore the aim of the textbook analysis was to investigate whether the coursebooks themselves conform to the requirements some of the youngest citizens in Poland are being faced with in order to become an integral part of such a society.

\section{Research justification}

\subsection{The information society}

The term information society ('johoka shakai') was introduced in 1963 by the Japanese ethnologist Tadao Umesao and later made widely recognizable by Kenichi Koyama. The functioning of the term in Europe was initiated in 1978 by the French sociologists Alain Minc and Simon Nora in their report L'informatisation de la Société (Goban-Klas and Sienkiewicz 1999: 420). It is also known as the 'knowledge society', which emphasizes the creation and sharing of knowledge for 
the benefit of people (Gajek 2008: 19). The report Recommendations of the Bangemann Group to the European Council (1994) brought about the best known definition of the information society as characterized by the preparation and the ability to use information systems; a society which uses telecommunications services to transmit and remotely process information. For such a society information processing via information and communication technologies is of a significant economic, social and cultural value (Web 1).

The development of information and communication technologies has been extremely dynamic in the $21^{\text {st }}$ century, resulting in huge transformations in all possible areas of human life: in economy, social life, culture and politics (Kozłowski 2013: 4). The traditional economy, derived from the industrial revolution, yields to the modern economy based on knowledge, which is the effect of the information revolution (Osiński 2005: 7). Information and communication technologies contribute to economic growth mostly due to the fact that their development is "one of the most important factors responsible for changes in the labor market in recent decades" (Sijko 2014: 10). The existing model of industrial, office and agricultural worker, whose not quite state-of-the-art but specialized qualifications were good enough throughout their whole professional life, is gradually becoming obsolete. Modern, fast-growing economy needs a mobile, active and creative employees, with many key competences, including ICT. Such people should be able to function in the conditions of highly globalised competition. In addition, they must be able to adapt to the rapidly changing reality, efficiently acquire or update the necessary qualifications and reduce the effects of the growing educational gap (Osiński 2005: 7-8).

The evidence for the above statements is provided by the results of the ongoing statistical research conducted by Statistics Poland (former Main Statistical Office): it turns out that $95.6 \%$ of Polish enterprises use computer hardware in their activity, and 93.6\% use Internet resources. Almost half (45.6\%) of employees use computers, and less than four out of ten use the Internet for business purposes (Wegner et al. 2018: 52, 55, 67).

Finally, in order to complete the picture of how ubiquitous ITC is nowadays, the use of public services online must be mentioned. The possibilities of the so-called e-government are regularly expanding, thus allowing not only the enterprises, but also individuals to handle matters in numerous offices. The network of online stores is increasing; more and more banks allow account servicing via the Internet. Online resources of academic, medical, scientific and technical, commercial, legal, economic and statistical information are growing. Thus, nearly every candidate entering the modern labor market must be able to use online services and resources efficiently (Osiński 2011: 4), otherwise they might end up unemployed or without any prospects for a prosperous career.

\subsection{The role of school in the information society}

One of the many aims of contemporary schools is to take an active part in the process of building the information society. David Crystal's prediction (2001) that the Internet and other ICT will have a significant impact on foreign language teaching is now considered confirmed, owing - among others - to a comprehensive review of the latest research and analysis of foreign language learn- 
ing strategies in the digital environment made by Gajek and Michońska-Stadnik (2017). Therefore, it is without a doubt true that each school subject, including every foreign language course, is supposed to complement the processes of information society formation. What is more, learners increasingly expect language schools to integrate technology into teaching (Dudeney \& Hockly 2007: 8). And since one of the main foreign language teachers' goals is to prepare the student to use language in natural conditions, thus computers and consequently the Internet are the basic tools to fulfil this postulate, because - as Gajek (2000: 115) remarks - the Internet is one of the places where English is used naturally to communicate between people of different nations.

Such a tendency has also been duly noted and described extensively by the experts from the Ministry of National Education in the 'Reform of Education' presentation (RE). The document recommends a broader inclusion of individual ICT subjects into the core curriculum, which will enable the development of digital literacy and literacy skills (RE 2017: 8). This, in turn, is reflected in the tasks all primary schools must undertake. The most important of them is preparing students to learn a set of various skills: being able to make conscious and responsible choices while using the resources available on the Internet, along with critical analysis of information, safe navigation in the digital space, including establishing and maintaining a respectful relationship with other network users (CC 2017: 7).

The list of simple written statements that the student must understand now includes e-mails, text messages, forum and blog posts. The scope of required written forms which the student should be able to understand and create has been extended: by adding text messages and blog/chat/forum posts (e-mail letters had already been mentioned in the previous core curriculum). The students are now expected to use original sources of information in a modern foreign language, also obtained as a result of using information and communication technology (CC 2017: 16-19).

However, the above cannot be considered as the only skills learners may acquire with the help of ICT tools. Mark Prensky, dubbing the new generation 'Digital Natives', notices that nowadays, when students are motivated to learn something, they have the tools to do so to the extent unfathomable for adults, because "the Digital Natives exploit this to the fullest, while ignoring, to a larger and larger extent, the things they are not motivated to learn, which , unfortunately, includes most, if not all, of their schoolwork" (2004: 9-10).

The use of modern technologies in learning foreign languages also serves to build motivation among weaker students. Sharma and Barrett (2007: 41) note that by using the Interactive Whiteboard (IWB) the teacher can show material on the wall for slower students who cannot cope quickly with finding the exercise on the printed page of the book. This will lead - in the light of research carried out by Gajek and Michońska-Stadnik (2017: 67) - to the students remembering words better because they will be able to associate them with their place on the textbook page or their position on the board.

The indications of bigger complementarity of traditional and digital teaching and learning of foreign languages is to be observed on a much larger scale (Gajek 2015). EFL coursebooks are gradually transforming into the so-called 'e-textbooks', or the new generation textbooks (Krajka 2012; Erbay \& Can 2012; Marczak 2013; Majer 2015; Gajek \& Michońska-Stadnik 2017), becoming 
fully 'blended-books' (Sharma \& Barrett 2007: 46-7). Teeler and Gray (2000), along with Krajka (2002) go even further, proposing to replace a traditional coursebook with the Internet to teach a foreign language online. The furthest in revolutionizing glottodidactics are the creators of the socalled Dogme ELT, rejecting the use of a globalized textbook (Thornbury 2006: 70). This remains in sharp contrast to the study carried out by Allen (2015) comparing the attitudes of Swedish teachers to the EFL textbooks with the latest research on digital skills. The results showed that despite the fact that ICT is making massive influence on language classrooms in technologically advantaged countries like Sweden, the coursebook package still has its place assured among trainee teachers, at least for the immediate future.

Whereas in Poland, the results of a study on the effectiveness of English language teaching in primary schools (BENJA; Muszyński et al. 2015) confirm the supremacy of a textbook as the basic in-class didactic material. Nine out of ten teachers use it in every lesson. Other teaching aids are used less frequently (except audio recordings), with the Internet being used only once during all 252 observed classes (Szpotowicz and Muszyński 2015: 99-100).

Since coursebooks still constitute the foundation of every language course, i.e. textbooks still dominate lessons, a good EFL coursebook should meet the ICT-use core requirements. It will allow a greater variety of in-class language tasks, and significantly facilitate the student's autonomy (Gajek 2008: 75), a factor so profusely emphasised in the process of the individualization of learning.

\section{Analysis of the use of ICT tools in coursebooks - quantitative research}

The quantitative transverse study described below has taken the form of an empirical internal micro-evaluation as defined by Korporowicz (1997: 278), a "systematic examination of the value or advantages of a specific object from the point of view of the criteria adopted for this purpose [...] in order to understand it better". The object in question comprised the textbooks, while the adopted criteria - the number of references to ICT tools in each of them.

\subsection{Defining ICT tools}

The term information and communication technologies (or: information and telecommunications technologies, information or communication technologies), covers a family of technologies that process, collect and send information in an electronic form (Web 1).

The list of ICT tools which EFL textbooks are normally provided with is regularly updated with the latest developments in the field (Dudeney \& Hockly 2007; Hismanoğlu 2011; Krajka 2012). The following ICT tools can be distinguished:

- audio CD,

- DVD,

- CD-ROM/IWB software,

- chat,

- e-mail, 
- $\quad$ social tools (blog, vlog, wiki, podcast),

- interactive website of the publisher,

- e-portfolio,

- project-based learning (PBL) work using the Internet,

- on-line games like Quizlet or Kahoot,

- digital presentations, e.g. PowerPoint.

Taking into account the content of the new Core Curriculum, the following issues established the focus of this research:

- lexical scope - science and technology,

- reading comprehension (e-mails, text messages, forum and blog posts),

- writing (text messages, blog/chat/forum posts and e-mail letters),

- encouraging students to do their own work using films, Internet resources, instant messaging and social media.

Before the study began, the construct had to be operationalized in the context of the studied textbooks, i.e. references to ICT tools had been divided into two types: explicit and implicit ones. Explicit references mean all rubrics referring to the use of ICT tools, for instance 'find on the Internet', 'record a vlog post', 'create a multimedia presentation'. Similar categories apply to the definition of implicit references, the difference - however - is in the lack of a literal command to use technology. In addition, implicit references include the use of ICT-related vocabulary, such as device names (e.g. 'a laptop', 'a notebook', 'a tablet'), the Internet content (e.g. 'a blog', 'a website', 'a post'), and names of activities (e.g. 'surfing the net', 'playing video games', 'chatting online'). As a result of this distinction, two separate lists of ICT references had been created.

Every time the term 'explicit references' appears in the text, it describes explicit instructions for the students to perform the following tasks:

- create Internet-based PBL work,

- create computer-based PBL work, e.g. word-processing,

- practise writing skills with ICT tools,

- $\quad$ send an e-mail,

- download files from a dedicated website.

'Implicit references' refer to any instance when ICT-related vocabulary is used, be it in the direct instructions, sample grammar sentences or random examples of free-time activities and the like. They include the following:

- an ICT-related wordlist,

- $\quad$ sources for a reading comprehension task (email, blog, website, text, etc.),

- a task in which writing skills are to be practised supposedly with ICT,

- an instruction to write a text/e-mail/blog post task,

- a separate unit on ICT,

- a PBL work supposedly done with ICT, 
- other, e.g. grammar exercise where a sample sentence contains ICT-related words or expressions.

It must be noted here that pictures or other graphic representations of gadgets/equipment or activities involving the use of information and communication technology might be understood as implicit references to ICT. They have not been taken into consideration in this study, though, in order not to blur the purely linguistic value of this research.

\subsection{Research material}

Each book comes from a different publisher. The selection criterion was receiving the approval number by the Ministry of National Education. Although there are 8 new series of EFL coursebooks for the new seventh grade, the willingness to treat all publishers equally resulted in the necessity of choosing one of two textbooks from the portfolio of two publishers (Oxford and Macmillan). Therefore, the content of six textbooks was analyzed, interestingly, one entirely in the electronic version on the e-Panel platform (English Class, Pearson), the other also in the .pdf file version (English Plus Options, Oxford).

The list of analyzed coursebooks for the seventh grade of the new primary school (in alphabetical order, in brackets the name of the publisher):

- All Clear (Macmillan),

- Citizen Z (PWN-Cambridge University Press),

- English Class (Pearson),

- English Plus Options (Oxford),

- Smart Time 1 (Express Publishing),

- Teen Explorer (Nowa Era/National Geographic).

\subsection{Research questions}

The newly-issued EFL coursebooks not only have to comply with the ministerial curriculum requirements, but also reflect the interests and needs of 14 -year-old students, the addressees of these textbooks. Therefore, it might be presumed that such coursebooks will contain a substantial number of references to ICT, thus allowing to see the influence of ICT on the contemporary world, or rather the textbook authors' view on that topic. These two hypotheses have set the ground for the following research questions:

- Which coursebook contains the biggest number of references to ICT?,

- What types of references are they? (Either explicit or implicit ones?),

- What role do ICT tools play in the portrayal of the 'Digital Natives' reflected in the coursebooks?

\subsection{Research methodology}

An empirical approach was used to evaluate the content of didactic materials according to the taxonomy of Alan Cunningsworth $(1984,1995)$, including a thorough assessment using a previously 
prepared list of criteria. Since pre-defined criteria lists are "a model framework, not a straitjacket" (Cunningsworth 1995: 5), they may not fit into any teaching context. Consequently, taking into consideration advice given by Williams (1983) and Sheldon (1988), who consistently encouraged teachers to create their own tools to evaluate textbooks, the author's very own research methodology had been developed. Bearing in mind the above-mentioned features of the new Core Curriculum, the total number of pages of individual textbooks (without tables of contents and lists of irregular verbs) had been set against the number ICT references found as a result of thorough page-by-page analysis. Data obtained in such a way can objectively show the differences together with similarities (illustrated in Figs. 1-5) between the six coursebooks in question. Also, they can make it possible to attempt to draw a portrayal of the way the authors see teenagers' functioning in the society (Figs. 7-9).

\subsection{Results}

The results of the research are shown below in a series of tables (Figs. 1-5). Two main tables (Fig. 1 and Fig. 3) illustrate the order the coursebooks have been arranged in to emphasise the total numbers of references contained therein. The other tables, which comprise more details concerning the nature of references themselves, see the coursebooks put in a simple alphabetical order.

As it is indicated in Figure 1, Smart Time tops the ranking of explicit references. It is the only one of the analyzed textbooks which contains sixteen separate tasks specifically labelled ICT, thanks to which a teacher and students can clearly understand what didactic tools they are expected to use.

Fig. 1. Number of explicit ICT references in each of the coursebooks

\begin{tabular}{|c|c|c|c|}
\hline \multirow{2}{*}{ Coursebook } & \multirow{2}{*}{$\begin{array}{l}\text { Total number of } \\
\text { pages }\end{array}$} & \multicolumn{2}{|c|}{ Explicit references } \\
\hline & & $\begin{array}{l}\text { Total } \\
\text { number }\end{array}$ & $\%$ \\
\hline Smart Time & 170 & 16 & 9.41 \\
\hline English Plus Options & 124 & 7 & 6.45 \\
\hline English Class & 129 & 7 & 5.43 \\
\hline All Clear & 126 & 6 & 4.76 \\
\hline Teen Explorer & 169 & 6 & 3.35 \\
\hline Citizen $Z$ & 129 & 1 & 0.78 \\
\hline Average & 141 & 7 & 5 \\
\hline
\end{tabular}

Two of the analyzed textbooks show a significant deviation from the average (see Fig. 1 above), rounded to full values. Smart Time contains the highest number of unequivocal - it seems - refer- 
ences to ICT tools, while the remaining four coursebooks (not Citizen Z) are carefully using PBL work, referring to the Internet or other ICT tools in a moderate number: All Clear suggests preparing a digital wall only once, English Class and English Plus Options both suggest making six digital presentations, while Teen Explorer encourages learners to create four vlog entries. Citizen $Z$ clearly stands out, having no explicit ICT references whatsoever, except the possibility to download audio files from a dedicated website, a feature shared by all remaining five coursebooks (Fig. 2).

Fig. 2. Types of explicit ICT references in each of the coursebooks

\begin{tabular}{|c|c|c|c|c|}
\hline \multirow[b]{3}{*}{ Coursebook } & \multicolumn{4}{|l|}{ Explicit references } \\
\hline & 1. & 2. & 3. & 4. \\
\hline & $\begin{array}{l}\text { downloadable } \\
\text { listening } \\
\text { comprehension } \\
\text { files }\end{array}$ & $\begin{array}{l}\text { Internet- } \\
\text { based project }\end{array}$ & $\begin{array}{l}\text { ICT-based } \\
\text { project }\end{array}$ & $\begin{array}{l}\text { ICT-based } \\
\text { writing task }\end{array}$ \\
\hline All Clear & 1 & 4 & 1 & - \\
\hline Citizen $Z$ & 1 & - & - & - \\
\hline English Class & 1 & 6 & - & - \\
\hline $\begin{array}{l}\text { English Plus } \\
\text { Options }\end{array}$ & 1 & 4 & 1 & 1 \\
\hline Smart Time & 1 & 8 & 1 & 6 \\
\hline Teen Explorer & 1 & 1 & 4 & - \\
\hline Average & 1 & 3.83 & 1.17 & 1.17 \\
\hline
\end{tabular}

When it comes to implicit ICT references (Fig. 3.), Teen Explorer holds the first place, but with Smart Time, English Class and English Plus Options trailing right behind it, respectively. Citizen $Z$ and All Clear both fall far behind the leaders, not only in the ranking of total number of references, but also when it comes to percentage results. 
Fig. 3. Number of implicit ICT references in each of the coursebooks

\begin{tabular}{|l|l|l|l|}
\hline \multirow{2}{*}{ Coursebook } & \multirow{2}{*}{$\begin{array}{l}\text { Total number of } \\
\text { pages }\end{array}$} & \multicolumn{2}{|l|}{ Implicit references } \\
\cline { 2 - 4 } & total number & $\mathbf{\%}$ \\
\hline Teen Explorer & 169 & 67 & 39.65 \\
\hline Smart Time & 170 & 62 & 36.47 \\
\hline English Class & 129 & 47 & 36.43 \\
\hline $\begin{array}{l}\text { English Plus } \\
\text { Options }\end{array}$ & 124 & 45 & 36.29 \\
\hline Citizen Z & 129 & 29 & 22.48 \\
\hline All Clear & 126 & 26 & 20.64 \\
\hline Average & $\mathbf{1 4 1}$ & $\mathbf{4 6}$ & $\mathbf{3 2}$ \\
\hline
\end{tabular}

As far as the type of implicit references is concerned, the differences between coursebooks are easily spotted (see Fig. 4, where the category of ICT-related vocabulary items has been omitted on purpose in order to be discussed later in this paper). However, it can be observed that some categories (i.e. wordlists, separate sub-/units and ICT-based projects) provide similar results since each textbook contains a comparable number of items in question. What must be surprising is the fact that both Smart Time and Teen Explorer do not use many ICT-looking sources in their reading comprehension tasks (just only two and three respectively), whereas Citizen $Z$ - a "marauder" in many instances - holds the first place with as many as eight texts (see Fig. 4). 
Fig. 4. Types of implicit ICT references in each of the coursebooks

\begin{tabular}{|c|c|c|c|c|c|c|c|c|}
\hline \multirow[b]{3}{*}{ Coursebook } & \multicolumn{8}{|c|}{ Implicit references } \\
\hline & 1. & 2. & 3. & 4. & 5. & 6. & 7. & 8. \\
\hline & 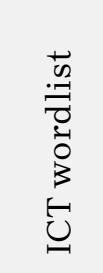 & 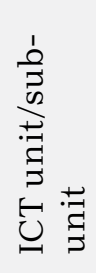 & 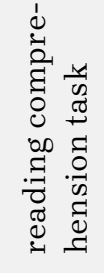 & 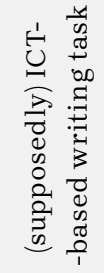 & 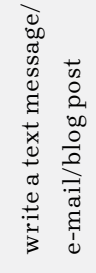 & 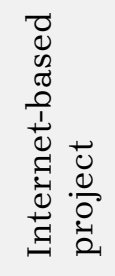 & 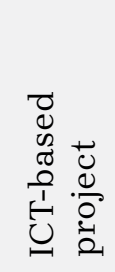 & $\begin{array}{l}\overrightarrow{0} \\
\stackrel{ \pm}{0}\end{array}$ \\
\hline All Clear & 1 & 1 & 6 & - & 2 & 1 & 1 & 10 \\
\hline Citizen $Z$ & - & 1 & 8 & 1 & 7 & - & - & 5 \\
\hline English Class & 1 & 1 & 7 & 3 & 6 & - & 1 & 18 \\
\hline $\begin{array}{l}\text { English Plus } \\
\text { Options }\end{array}$ & - & 2 & 5 & - & 6 & 2 & 1 & 9 \\
\hline Smart Time & 1 & 2 & 2 & 7 & 13 & 1 & 1 & 11 \\
\hline Teen Explorer & 1 & 1 & 3 & 1 & 10 & - & - & 15 \\
\hline Average & 0.67 & 1.5 & 5.17 & 2 & 7.33 & 0.67 & 0.67 & 11.33 \\
\hline
\end{tabular}

Half of the textbooks devote one separate unit to modern technologies. In All Clear it is a 10page unit entitled 'Connected', however, it is difficult to find any mention of ICT on altogether three pages. English Class and English Plus Options in their units ('New Technology' and 'Communication') on each of the nine and twelve pages, respectively, present relatively a lot of references to ICT. Moreover, English Plus Options has an additional separate topic in the 'Options Extra Listening And Speaking' section. In Citizen $Z$ references to ICT can be found on only five pages of the 10-page unit 'The Easy Life', but unlike other coursebooks, it offers a discussion about the need to use computers in class and bringing telephones to school. Smart Time does not contain a separate unit on technology, only short sections on the vocabulary of 'Science and Technology' and 'Computers', similarly to the Teen Explorer - but there is no separate technology section in the 'Let's get together' unit.

It is also interesting to compare two results of vocabulary search: the number of ICT-related vocabulary items scattered all over the coursebooks on many different pages in many different contexts with ICT-related lexis listed on specially prepared wordlist (see Fig. 5). 
Fig. 5. Number of ICT-related vocabulary items on wordlists and elsewhere in each of the coursebooks

\begin{tabular}{|l|l|l|}
\hline Coursebook & $\begin{array}{l}\text { ICT-related vocabulary } \\
\text { items on wordlists }\end{array}$ & $\begin{array}{l}\text { ICT-related vocabulary } \\
\text { items elsewhere }\end{array}$ \\
\hline Smart Time & 44 & 36 \\
\hline English Class & 62 & 10 \\
\hline All Clear & 28 & 4 \\
\hline Teen Explorer & 11 & 23 \\
\hline English Plus Options & 0 & 20 \\
\hline Citizen Z & 0 & 7 \\
\hline Average (rounded ) & $\mathbf{2 4}$ & $\mathbf{1 7}$ \\
\hline
\end{tabular}

The undisputed leader of ICT content wordlist is English Class: the 'Gadgets and technology/ Computer equipment' list contains as many as 62 items. Smart Time has 43 words and expressions, but they are all scattered on several wordlists, as is the case with other use of ICT lexis (36 items). All Clear comprises a list of words entitled 'IT activities' containing only 14 words and expressions, but there are also 14 other vocabulary items to be found on different wordlists. Similarly, in Teen Explorer - the list titled 'Technology' has 10 items, of which only 7 can be understood as ICT tools. And finally, Citizen $Z$ and English Plus Options do not contain any separate wordlists.

The content of Figures 6 and 7 has been obtained either by carefully scrutinizing units devoted to students' out-of-school activities (Citizen Z and English Plus Options) or corresponding wordlists (the remaining four books), and does not cover the other parts of the textbooks due to time constraints for this particular research. 
Fig. 6. ICT-related free-time activities vs. other free-time activities

\begin{tabular}{|l|l|l|l|}
\hline \multirow{2}{*}{ Coursebook } & \multicolumn{2}{|l|}{ Total number of free-time activities } \\
\cline { 2 - 4 } & ICT-related & Non-ICT-related & ratio \\
\hline Smart Time & 4 & 4 & 1 \\
\hline English Class & 7 & 9 & 0.78 \\
\hline English Plus Options & 7 & 13 & 0.62 \\
\hline All Clear & 5 & 14 & 0.36 \\
\hline Citizen Z & 4 & 10 & 0.3 \\
\hline Teen Explorer & 4 & 28 & 0.14 \\
\hline Average & $\mathbf{5}$ & $\mathbf{1 3}$ & $\mathbf{0 . 5 3}$ \\
\hline
\end{tabular}

As for the actual ICT-related free-time activities found mostly on wordlists, the authors see teenagers mostly play computer games and blog or chat online. Surprisingly, listening to music on the web is not seen as particularly popular (Fig. 7).

Fig. 7. Distribution of ICT-related free-time activities in coursebooks

\begin{tabular}{|c|c|c|c|c|c|c|c|c|c|c|c|}
\hline \multirow[b]{2}{*}{ Coursebook } & \multicolumn{11}{|c|}{ ICT-related free-time activities } \\
\hline & 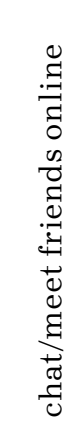 & 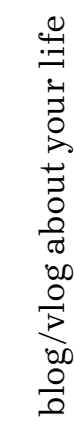 & 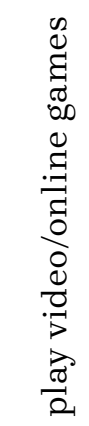 & 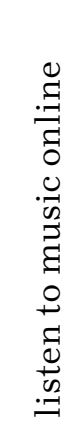 & 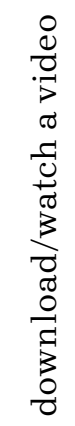 & 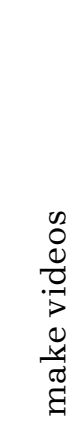 & 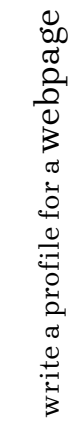 & 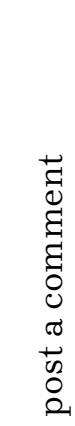 & 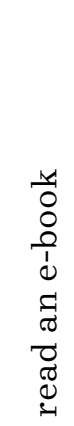 & 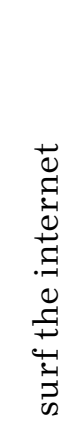 & 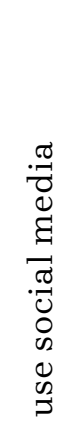 \\
\hline All Clear & & $\mathrm{v}$ & $\mathrm{v}$ & & $\mathrm{v}$ & & & $\mathrm{v}$ & $\mathrm{v}$ & & \\
\hline Citizen $Z$ & $\mathrm{v}$ & $\mathrm{v}$ & $\mathrm{v}$ & & & & & & $\mathrm{v}$ & & \\
\hline English Class & $\mathrm{v}$ & $\mathrm{v}$ & $\mathrm{v}$ & $\mathrm{v}$ & $\mathrm{v}$ & & & & & $\mathrm{v}$ & $\mathrm{v}$ \\
\hline $\begin{array}{l}\text { English Plus } \\
\text { Options }\end{array}$ & $\mathrm{v}$ & $\mathrm{v}$ & $\mathrm{v}$ & $\mathrm{v}$ & $\mathrm{v}$ & $\mathrm{v}$ & $\mathrm{v}$ & & & & $\mathrm{v}$ \\
\hline Smart Time & & $\mathrm{v}$ & $\mathrm{v}$ & $\mathrm{v}$ & & & & & & $\mathrm{v}$ & \\
\hline Teen Explorer & & $\mathrm{v}$ & $\mathrm{v}$ & $\mathrm{v}$ & & & & $\mathrm{v}$ & & & \\
\hline
\end{tabular}


The number of ICT-related jobs that have found their way onto the pages of the coursebooks turns out to be nearly non-existent (Fig. 8). What is more, the authors' creativity is basically limited to 'an IT specialist' or 'a computer programmer'.

Fig. 8. Number of ICT-related jobs in each of the coursebooks

\begin{tabular}{|l|l|}
\hline Coursebook & Total number of ICT-related jobs \\
\hline English Plus Options & 2 \\
\hline All Clear & 1 \\
\hline English Class & 1 \\
\hline Smart Time & 1 \\
\hline Teen Explorer & 1 \\
\hline Citizen Z & 0 \\
\hline
\end{tabular}

\section{Discussion}

The fact that each of the coursebooks has been written by different authors implies substantial differences among them, even though they have to meet the same ministerial standards. It is true when it comes to their layout, structuring of tasks and overall content. The approach to information and communication technology is yet another kettle of fish.

Nearly all the textbook authors follow the current trends in ELT methodology by the means of including a moderate amount of PBL work in which ICT tools must be used by students. Smart Time and English Plus Options lead the way, whereas Citizen $Z$ turns out to be their absolute opposite - the practical use of new technologies suggested in this textbook is almost imperceptible.

In terms of texts which aim to strengthen reading comprehension skills, the so-called semiauthentic articles from traditional magazines are in quite an abundance (especially in Citizen Z). However, all the textbooks contain texts for practicing other language skills (speaking, listening comprehension, broadening the vocabulary, grammar, writing), which resemble blog posts, e-mail letters or articles from websites. Their number in four of the coursebooks is at a very similar level, with Smart Time and Teen Explorer at the bottom of the list, surprisingly.

Regarding the writing skills, no textbook contains the instruction 'write a text message/email letter and send it' or 'create a blog post and upload it' - most textbooks recommend writing these forms in a notebook, except in Smart Time, where it is not actually specified. In English Plus Options every task from the 'Writing' section is accompanied by the rubric 'write a text message in a notebook', but in one case the textbook tells the learner to consult the Internet in order to find examples in the 'Study Strategy'. 
The interpretation of the obtained results does not allow, obviously, to determine which coursebook is the best. On their basis, teachers can only find a book that both meets their expectations and best suits the needs of students. In terms of complying with the requirements of the new Core Curriculum, it was found that the more references to ICT (of both types) there are in the coursebook, the more it meets these requirements.

As for the portrayal of the 'Digital Natives' as the most influential formative group of the Internet society, the coursebooks present two main areas: teenagers' free-time activities, along with their future ICT-related jobs. First and foremost, it can be easily observed that according to the creators of all the coursebooks in question all written communication these days is done via ICT tools like smartphones or laptops. The sources of many reading texts to be found in the coursebooks comprise excerpts from blogs, websites, emails or text messages. It is the ministerial requirements, though, that make pupils write text messages, e-mail letters and so on in their paper notebooks, since the coursebooks are not owned by students and must be returned to schools at the end of the schoolyear. Also, every textbook contains a separate unit where discussion about modern technologies plays a vital role ("Connected" - All Clear, "The easy life" - Citizen Z, "New technology" - English Class, "Communication” - English Plus Options, "Predictions" - Smart Time, "Let's get together" - Teen Explorer). These titles clearly state the main purpose why ICT tools are used these days - to communicate with other people now and in the future.

It is interesting to see what examples, in the authors' view, teenagers usually give as their leisure activities (Figs. 6 and 7). It is clearly visible in the instances of possible answers pupils are provided with when asked a question "How do you usually spend free time?". It can be observed, then, that ICT-related free-time activities take up approximately a third of the total number of leisure activities. The only exception is Teen Explorer with its 0.14 ratio, which may be caused by the publisher's angle at lifestyle - it is National Geographic, after all.

It is worth noting that only two coursebooks mention the newest trends in leisure activities, i.e. uploading content on Instagram, YouTube and Twitter (English Class) or posting on Facebook and watching live-streamed shows on Netflix or YouTube (English Plus Options). The reasons behind this fact might lie in the possible copyright violations. Finally, texting and sending emails have apparently become such routine activities that they are no longer understood as leisure.

The ICT-related jobs are actually a scarce (Fig. 8). All Clear emphasises the role of ICT in future career (reading comprehension text titled "The power of technology", p. 19), while English Class mentions only one ICT-related job - an IT specialist, describing it as a job in which you will "fix things with your hands" (p. 94). A computer programmer 'populates' All Clear (p. 19 and 120), English Plus Options (p. 62) and Smart Time (p. 76) although reading comprehension texts found in the latter describe "self-cleaning buildings" and cars "communicating with traffic lights" (p. 106) or reminding you to take medicine (p. 121), but never mention the people responsible for such inventions, only inviting students to visit a "an exciting robot exhibition" at the local Science Museum (p. 115). In Teen Explorer we can find references only to robotics (building and programming robots, p. 106). Only one textbook (English Plus Options, p. 122) mentions a YouTube 
streamer, but this job title is never actually quoted. The reason for a small number of ICT-related jobs might be quite simple: the authors disregard the potential such work has for the future.

The quantitative research method described above has some limitations: the juxtaposition of only the number of pages on which references to ICT tools appear with the total number of pages in each of the textbooks certainly raises doubts as to the accuracy of the procedure itself. It should be emphasized that the method of counting references has its certain drawbacks and limitations, because, for example, wordlists have been counted as one reference, yet they differ in terms of the number of actual words and phrases they contain.

Therefore, it seems that the internal qualitative approach analysis of references might complement the first study with relevant content and key conclusions crucial for obtaining the 'big picture'. The most complete description of the usefulness of ICT tools referenced in the analyzed textbooks would be brought about by an additional research consisting of a series of interviews with teachers currently using these coursebooks.

The next phase of research on textbooks could be carrying out an innovative glottodidactic experiment (Komorowska 1982: 111): selecting two groups of students in every school where each textbook is used (6 schools in total - a different textbook in each of them). One of the groups (experimental) would be taught English using the Internet-based project work, the second one - a control group, implementing a 'normal' curriculum, devoid of projects. The pretest would be to test the ICT knowledge of the seventh grade students using the test and self-evaluation of computer skills. Then, in the eighth grade, a post-test should be carried out to check the above-mentioned knowledge.

\section{Conclusion}

The conclusions that arise as a result of the research described above can be used by the authors of the analyzed textbooks, as well as by the creators of the new ones. It is suggested to introduce more instructions that recommend the practical use of ICT tools, not only when included in the process of creating project work. In addition, teachers choosing modern multi-year textbooks could add a new category ('ICT references') to long evaluation lists proposed by Łuczak-Łomża and MeteraDebaene (2002: 7-8), or Kusiak-Piskowacka (2014: 70-71), which would increase the probability of choosing a better textbook, thus allowing to achieve better teaching results (Łuczak-Łomża and Metera-Debaene 2002: 5). What is more, coursebooks might prove an invaluable source of information about teenagers, provided they portray a thorough and true image.

Krajka (2007: 261) understood the need to develop an Internet-based component to supplement coursebook teaching in order to develop students' language proficiency by the means of "exploiting authentic and motivating language input in truly engaging yet pedagogically sound tasks". Currently, his ideas have been implemented and almost all coursebooks available on the Polish market are provided with additional software, and teachers can use it in the classroom instead of using the traditional textbook. Since coursebooks and ICT have been used for some time during English lessons, why not interact with them in hand? It seems that the creators of textbooks (both 
authors and publishers) should take advantage of the plethora of educational software available on the Internet and correlate some of the textbook tasks with it. This could mean an arduous workload for many lawyers due to the need to sign cooperation agreements, but both sides would surely benefit from tangible benefits: coursebooks would become more modern (Sharma \& Barrett 2007: 46) by providing materials via the Internet, while publishers would ensure that the coursebooks are kept up to date, generating more traffic on the websites of software producers.

The necessity of complementary digital and traditional learning and teaching of foreign languages seems to be inevitable, because "new technology does not add or take anything away - new technology changes everything" (Postman 1992, quoted in: Gajek 2015: 123). For this reason, Koralewska (2008: 216) indicates that "it is necessary to ensure practical experience" among teachers, whereas Krajka considers the necessity of educating foreign language teachers in the field of the newest technologies (2012) and using them 2016). These notions have already been reflected for example, at the postgraduate studies 'Technologies and new media in teaching English' at the School of Philology in Wroclaw, where 216 out of 276 hours planned in the syllabus are practical classes (Web 2). Such directions in teacher education must have positive didactic effects, since - as indicated by Zarzycka (2014: 332) - exemplary $21^{\text {st }}$ century foreign language teachers are educators who will take time to acquire ICT competences and make them not only an effective teaching tool, but also a tool enjoyed by both themselves and their learners. This, in turn, might prove beneficial in the upcoming years and allow the 'Digital Natives' to "go further in their learning than ever before - far beyond their teachers' ability and knowledge, and far beyond what even adults could have done in the past" (Prensky 2004: 9) and not ignore the schoolwork.

\section{References}

Allen, Christopher. 2015. Marriages of convenience? Teachers and coursebooks in the digital age. ELT Journal 69 (3). 249-263.

Crystal, David. 2006. Language and the Internet. Second edition. Cambridge: Cambridge University Press.

Cunningsworth, Alan. 1984. Evaluating and Selecting EFL Teaching Materials. London: Heinemann Educational Books.

Cunningsworth, Alan. 1995. Choosing Your Coursebook. London: Heinemann.

Dudeney, Gavin and Nicky Hockly. 2007. How to Teach English with Technology. Harlow: Pearson Education Limited.

Erbay, Asli and Seckin Can. 2012. Investigating the effectiveness of using interactive software instead of traditional coursebook in a university context, EDULEARN12 Proceedings. 991-994. https://library.iated.org/view/ERBAY2012INV (7 November 2017).

Gajek, Elżbieta. 2000. Komputery w nauczaniu języków obcych. In: Hanna Komorowska (ed.), Nauczanie języków obcych w zreformowanej szkole, 115-134. Warszawa: Instytut Badań Edukacyjnych. 
Gajek, Elżbieta. 2008. Edukacja językowa w społeczeństwie informacyjnym. Warszawa: Instytut Lingwistyki Stosowanej Uniwersytetu Warszawskiego.

Gajek, Elżbieta. 2015. Komplementarność cyfrowego i tradycyjnego uczenia się i nauczania języków obcych. Roczniki Kulturoznawcze VI (4). 123-140.

Gajek, Elżbieta and Anna Michońska-Stadnik. 2017. Strategie uczenia się języków obcych w Warszawa: Instytut Lingwistyki Stosowanej WLS UW.

Gajewska-Dyszkiewicz, Agata, Katarzyna Paczuska, Mariusz Marczak, Joanna Pitura, Marek Muszyński, and Magdalena Szpotowicz. 2016. Osiągnięcia gimnazjalistów w zakresie języka angielskiego. Podstawa programowa wciąż niezrealizowana. Języki Obce w Szkole 2. 90-98.

Goban-Klas, Tomasz and Piotr Sienkiewicz. 1999. Społeczeństwo informacyjne: Szanse. zagrożenia. wyzwania. Kraków: Wydawnictwo Postępu Telekomunikacji.

Hismanoğlu, Murat. 2011. The integration of information and communication technology into current ELT coursebooks: a critical analysis. 3rd World Conference On Educational Sciences. Book Series: Procedia Social and Behavioral Sciences. Volume: 15. https://doi.org/10.1016/j.sbspro.2011.03.048 (5 June 2017).

Komorowska, Hanna. 1982. Metody badań empirycznych w glottodydaktyce. Warszawa: PWN.

Koralewska, Elżbieta. 2008. Wykorzystanie technologii przez nauczycieli języków obcych. In: Mirosław Pawlak, Marek Derenowski and Bartosz Wolski (eds.), Problemy współczesnej dydaktyki języków obcych, 205-216. Poznań-Kalisz: Wydział Pedagogiczno-Artystyczny UAM w Kaliszu.

Korporowicz, Leszek (ed.). 1997. Ewaluacja w edukacji. Warszawa: Oficyna Naukowa.

Kozłowski, Grzegorz et al. 2013. E-podręcznik dostępny dla wszystkich. Poradnik dla twórców elektronicznych materiałów edukacyjnych. Warszawa: Fundacja Instytut Rozwoju Regionalnego.

Krajka, Jarosław. 2002. Nauczanie języka obcego w sieci - wykorzystanie Internetu jako alternatywy dla podręcznika. In: Wacław Strykowski (ed.), Media i Edukacja w dobie integracji, 231-241. Poznań: eMPi².

Krajka, Jarosław. 2007. English Language Teaching in the Internet-assisted Environment. Lublin: Wydawnictwo Uniwersytetu Marii Curie-Skłodowskiej.

Krajka, Jarosław. 2012. The Language Teacher in the Digital Age - Towards a Systematic Approach to Digital Teacher Development. Lublin: Wydawnictwo Uniwersytetu Marii Curie-Skłodowskiej.

Krajka, Jarosław. 2016. Język angielski. ale jaki? O kształceniu nauczycieli języka angielskiego w dobie globalizacji. Linguodidactica XX. 177-193.

Kusiak-Pisowacka, Monika. 2015. Ewaluacja podręcznika w nauczaniu języków obcych. Lingwistyka Stosowana 4. 65-75.

Łuczak-Łomża, Aleksandra and Ewelina Metera-Debaene. 2002. Zanim wybierzesz podręcznik. Metody oceniania materiałów do nauki języków obcych. Fraszka Edukacyjna. Warszawa.

Majer, Halina. 2015. Podręczniki elektroniczne drogą do autonomii ucznia? In: Mirosław Pawlak (ed.), Autonomia w nauce języka obcego - techniki, strategie, narzędzia, 135-148. Konin-KaliszPoznań: PWSZ w Koninie and Wydział Pedagogiczno-Artystyczny UAM w Kaliszu. 
Marczak, Mariusz. 2013. Selecting An E-(Text)Book: Evaluation Criteria. Teaching English with Technology 13(1). 29-41.

Muszyński, Mariusz, Dorothy Campfield and Małgorzata Szpotowicz. 2015. Język angielski w szkole podstawowej - proces i efekty nauczania. Wyniki podłużnego badania efektywności nauczania jezyka angielskiego 2011-2014. Warszawa: Instytut Badań Edukacyjnych. http://eduentuzjasci.pl/badania/110-badanie/726-badanie-efektywnosci-nauczaniajezyka-angielskiego-w-szkole-podstawowej.html (11 November 2017).

Ostrowska, Małgorzata and Danuta Sterna. 2015. Technologie informacyjno-komunikacyjne na lekcjach. Przykładowe konspekty i polecane praktyki. Warszawa: Centrum Edukacji Obywatelskiej.

Osiński, Zdzisław. 2005. Technologia informacyjna w edukacji humanistycznej. Toruń: Wyd. MADO.

Osiński, Zdzisław. 2011. Bariery wykorzystania Internetu w polskiej edukacji, In: T. Grabiński (ed.), Rola informatyki $w$ naukach ekonomicznych i społecznych. Innowacje i implikacje interdyscyplinarne. Tom 2, 287-96. Kielce: Wydawnictwo Wyższej Szkoły Handlowej.

Postman, Neil. 1992. Technopoly: the Surrender of Culture to Technology. New York: Knopf.

Prensky, Marc. 2004. The Emerging Online Life of the Digital Native: What they do differently because of technology, and how they do it. www.marcprensky.com (15 July 2018).

Rybarczyk, Renata. 2006. Podręcznik - komputer - Internet. O możliwości skutecznego stosowania nowych technologii informacyjno-komunikacyjnych $\mathrm{w}$ procesie nauczania i uczenia się języka niemieckiego na poziomie elementarnym w gimnazjum. In: Jolanta Krieger-Knieja and Urszula Paprocka-Piotrowska, U. (eds.), Komunikacja językowa w społeczeństwie informacyjnym: nowe wyzwania dla dydaktyki języków obcych, 400-406. Lublin: Towarzystwo Naukowe Katolickiego Uniwersytetu Lubelskiego Jana Pawła II.

Sharma, Pete and Barney Barrett. 2007. Blended Learning. Using technology in and beyond the language classroom. Oxford: Macmillan Publishers Limited.

Sheldon, Leslie E. 1988. Evaluating ELT Textbooks and Materials. ELT Journal 42 (4). 237-246.

Sijko, Kamil et al. 2014. Kompetencje komputerowe i informacyjne młodzieży $w$ Polsce. Raport $z$ międzynarodowego badania kompetencji komputerowych i informacyjnych ICILS 2013. Warszawa: Instytut Badań Edukacyjnych. http://eduentuzjasci.pl/publikacje-ee-lista/ raporty/206-raport-z-badania/kompetencje-komputerowe-i-informacyjne-mlodziezy-wpolsce/1135-kompetencje-komputerowe-i-informacyjne-mlodziezy-w-polsce-raport-icils. html (31 December 2017).

Szpotowicz, Magdalena and Marek Muszyński. 2015. Jak wyglądają lekcje języka angielskiego w szkole podstawowej? Wyniki Badania efektywności nauczania języka angielskiego (BENJA). Jezzyki Obce w Szkole 4. 98-104.

Teeler, Dede and Peta Gray. 2000. How to use the Internet in ELT. Harlow: Pearson Education Limited.

Thornbury, Scott. 2006. An A-Z of ELT. Oxford: Macmillan Education. 
Wegner, Magdalena et al. 2018. Społeczeństwo informacyjne w Polsce. Wyniki badań statystycznych z lat 2013-2017. Urząd Statystyczny w Szczecinie: Ośrodek Statystyki Nauki, Techniki, Innowacji i Społeczeństwa Informacyjnego. www.stat.gov.pl, (01 September 2018).

Williams, Dawid. 1983. Developing criteria for textbook evaluation. ELT Journal 37 (3). 251-255.

Zarzycka, Grażyna. 2014. Media w nauczaniu języków obcych. Koncepcje teoretyczne i wybrane rozwiązania metodyczne. Acta Universitatis Lodziensis. Kształcenie Polonistyczne Cudzoziemców 21. 321-333.

\section{Coursebooks:}

Bandis, Angela and Diana Shotton. 2017. Teen Explorer. Podręcznik dla kasy 7. Warszawa: National Geographic Learning/Nowa Era.

Evans, Virginia and Jenny Dooley. 2017. Smart Time 1 Do nowej podstawy programowej. Newbury: Express Publishing.

Hastings, Bob, Stuart McKinley and Arek Tkacz. 2017. English Class A2+. Warszawa: WSiPPearson Central Europe.

Howarth, Patrick, Patricia Reilly and Daniel Morris, 2017. All Clear. Warszawa: Macmillan.

Puchta, Herbert 2017. Citizen Z. Warszawa: Cambridge University Press/PWN.

Wetz, Ben and Diana Pye. 2017. English Plus Options. Oxford: Oxford University Press.

\section{Documents}

Podstawa programowa kształcenia ogólnego. Szkoła podstawowa. język obcy nowożytny. 2017. Ministerstwo Edukacji Narodowej/Ośrodek Rozwoju Edukacji. www.men.gov.pl/wp-content/ uploads/2011/02/men_tom_3.pdf (10 November 2017).

Recommendations to the European Council. 1994. Bangemann Report, Europe and the Global Information Society. http://www.cyber-rights.org/documents/bangemann.htm (24 December 2017).

Reforma edukacji 2017. Zmiany w kształceniu ogólnym. specjalnym i zawodowym oraz w obszarze wychowania i profilaktyki. 2017. Ministerstwo Edukacji Narodowej/Ośrodek Rozwoju Edukacji. http://www.cen.gda.pl/wp-content/uploads/2017/06/Reforma-edukacji-2017.-Zmiany-wkszta\%C5\%82ceniu-og\%C3\%B3lnym-specjalnym-i-zawodowym-oraz-w-obszarze-wychowania-iprofilaktyki.pdf (10 November 2017).

\section{Web pages}

Web 1 - Fundacja Rozwoju Systemu Edukacji. http://www.frse.org.pl. (15 November 2017).

Web 2 - The Philological School of Higher Education in Wrocław. https://www.wsf.edu.pl/studia-podyplomowe,kierunki_studiow_podyplomowych.xml (01 May 2017). 